\title{
The Internet and Indonesian Women Entrepreneurs: Examining the Impact of Social Media on Women Empowerment
}

\author{
Ezmieralda Melissa, Anis Hamidati, Muninggar Sri Saraswati, \\ and Alexander Flor
}

\section{Introduction}

\subsection{Background}

Unemployment is one of the major challenges that Indonesia faces. Home to over 230 million, Indonesia has an unemployment rate of $2.6 \%$ among a labour force of 107.7 million (Badan Pusat Statistik 2010). Of this number, the working population is pegged at 104.9 million, comprising 66.8 million men and 38.1 million women (ibid.). The unemployment rate appears to be moderate. However, the Indonesian Statistics Bureau estimates that only $67.72 \%$ of the working force is regularly employed. Therefore, the actual unemployment rate at any given time is higher than the official figure.

There are many reasons behind unemployment in Indonesia. According to Danani (2004: p. 2), unemployment is 'the result of a combination of a multitude of circumstances and distinct factors, some acting on the supply side and others on the demand side'. Examples of supply factors are the age structure of population, fertility, education and the sustained rise in the economic well-being of the population. Meanwhile, the demand factors include the sectoral and status structure of employment as well as the pace of economic growth (ibid.).

E. Melissa $(\bowtie) \cdot$ A. Hamidati

Department of Communication and Public Relations, Swiss German University, Banten, Indonesia

e-mail: ezmieralda.melissa@sgu.ac.id

M.S. Saraswati

Asian Research Centre, Murdoch University, Murdoch, WA, Australia

A. Flor

Faculty of Information and Communication Studies, University of the Philippines

(Open University), Los Baños, Laguna, Philippines

A. Chib et al. (eds.), Impact of Information Society Research in the Global South, DOI 10.1007/978-981-287-381-1_11 
The Indonesian government has implemented several strategies to counter unemployment. In addition to opening job opportunities in the market through customary measures such as opening factories or other labour-intensive projects, it has encouraged its citizens to create work opportunities through entrepreneurship. A number of policies have been formulated to provide loans for new entrepreneurs to start or expand their businesses (Ardieansyah et al. 2011: p. 40). The government also provides training to improve citizens' business skills, organize exhibitions to showcase their products and so on (ibid.). All of these activities are conducted to increase the number of entrepreneurs from 0.18 to $2 \%$ of the total population, which is considered as the ideal ratio by the government (Antara 2012).

Many entrepreneurial projects in Indonesia target women mainly because the unemployment rate among women is higher than that of men. According to BPS (2010), the unemployment rate among women is $3.6 \%$ compared to $2.0 \%$ among men. Another equally important reason is the fact that Indonesian women are not particularly ignorant about entrepreneurship. Instead, Indonesian women have been involved in business despite limited public acknowledgement. In 2011, the Ministry of Women Empowerment and Child Protection reported that there are 55,206,444 micro-, small and medium enterprises ${ }^{1}$ in Indonesia. It is estimated that $60 \%$ of these enterprises are run by women (Kementrian Koperasi dan Usaha Kecil Menengah 2008). As a result, women are seen not only to have potential but as capable and resilient entrepreneurs as well.

Another significant fact about entrepreneurship in Indonesia is revealed by the Indonesian Women's Business Association (IWAPI). This association reported that around $85 \%$ of businesses run by women are micro- and small businesses, while $13 \%$ are medium enterprises and only $2 \%$ are big businesses (IWAPI in Widyadari et al. 2006: p. 4). Most of these micro- and small businesses are operated from home and manufacture products such as handicrafts, traditional food, clothing items and so on (ibid.) Unfortunately, there is no existing data that explains how many of these businesses are ICT based.

Entrepreneurship provides both benefits and challenges to women. On the one hand, it enables them to generate additional income for themselves and their families, create jobs and, eventually, actively contribute to the country's economy (see Sarri and Trihopoulou 2005). On the other hand, women also have to face many challenges involving financing, business skills, networks and support groups, among other things, to be able to set up their own business (Coleman 2000; Cromie and Birley 1992).

\footnotetext{
${ }^{1}$ In Indonesia, microenterprises refer to businesses with assets that are up to Rp 50 million and turnovers that are up to Rp 300 million. Meanwhile, small enterprises refer to business with assets that are in between Rp 50 million and Rp 500 million and turnovers that are in between $\mathrm{Rp} 300$ million and Rp. 2.5 billion. Finally, medium enterprises refer to business with assets that are in between Rp 500 million and Rp 10 billion and turnover that are in between Rp 2.5 billion and $\mathrm{Rp}$ 50 billion (Regulation No. 20/2008 on Micro, Small and Medium Enterprises).
} 
One of the main issues faced when opening a business is funding. Since many women quit their jobs after getting married, they do not have much savings to start their own company. In addition, Indonesians traditionally give more property ownership rights to men in conjunction to their role as head of the family. ${ }^{2}$ As a result, women normally have fewer assets that may be used as collateral for bank loans (Widyadari et al. 2006). Otherwise, they should get consent from their husbands - the ones holding the rights to the property - stating their legal responsibility to complete payments of the loans. Hence, if their husbands disapprove of their intention to work or if they are unmarried, it becomes difficult for women to fund their business.

The second challenge faced by women in becoming entrepreneurs is related to education. In many developing countries, women tend to have lower education than men (Coleman 2000; Cromie and Birley 1992). In Indonesia, merely $11.62 \%$ of Indonesian female entrepreneurs engaged in micro- and small businesses graduated from high school (Kementrian Pemberdayaan Perempuan dan Perlindungan Anak 2011). The majority $(75.5 \%)$ of them only finished elementary education. This is far lower than male entrepreneurs in the same business scale with $19.9 \%$ of them graduating from high school and $63.4 \%$ graduating from elementary schools (Kementrian Pemberdayaan Perempuan dan Perlindungan Anak 2011). As a consequence, women tend to have limited technical, technological and managerial skills to implement their business ventures.

Moreover, women have to face challenges in starting, grooming and expanding their business due to their limited social circles. It is widely known that social networks are important factors in entrepreneurship, particularly within the context of Asian countries (Gold and Guthrie 2002; Siong-Choy 2007; Carney et al. 2008). Without enough social capital gathered from these networks, entrepreneurs might not be able to survive in today's competitive market.

In addition to those factors, Indonesian women have to deal with balancing their career and family. This is actually a typical issue faced by many women workers in other countries (see Segal et al. 2005: p. 3; Lombard 2001: p. 216), but it is more prominent in developing countries, such as Indonesia and Vietnam (Van der Merwe and Lebakeng 2010; Nguyen 2005). The majority of Indonesians position men as breadwinners and women as homemakers. Therefore, although women, particularly educated women in urban areas, can enter the workforce, they cannot escape from their traditional role as homemakers.

\footnotetext{
${ }^{2}$ Many ethnicities in Indonesia practise patriarchal culture. In this culture, properties such as houses and land are inherited only to the males in the family. In addition, many Indonesians are also Muslims; according to the Islamic law, males receive twice as much inheritance as those received by the females. Both of these practices are implemented with reasoning that because men have a role as the head of the family, then they have to be responsible for the other family members.
} 


\subsection{Rationale}

The introduction of new information and communication technologies (ICTs) has brought new hopes to women entrepreneurship (Ndubisi and Kahraman 2006; Duncombe et al. 2005). One prominent feature of the Internet is the introduction of Web 2.0 enabling users to form and expand their networks online (O'Reilly 2009). This feature has been proven capable to support business entities, particularly in marketing-related activities (Jones 2010: p. 150). For existing and future women entrepreneurs, an innovation that is capable of forming and expanding networks can support them in overcoming challenges related to social capital. Considering the increase in the number of Indonesian Internet users from 500,000 in 1998 to 55 million users in 2011 (Markplus 2011), generating social capital through expanding networks can become a concrete possibility.

In Indonesia, the majority of Internet ${ }^{3}$ users access it mostly for social networking purposes. Indonesian Internet users have been widely acknowledged as ardent social media users. ${ }^{4}$ It is reported that 47.5 million Indonesians subscribed to Facebook in 2012 (Internet World Stats 2012), putting Indonesia fourth after the USA, Brazil and India in terms of total number of users (Socialbakers 2012). In addition to Facebook, there are around 19.5 million Twitter accounts in Indonesia, making it the fifth largest user population in the world in 2012 (Socialbakers 2012). Conventional blogging, which is also a form of social media, also remains popular among Indonesian Internet users. The number of blogs in Indonesia rose from less than 1 million in 2009 to 5.3 million in 2012 although only $32.7 \%$ were regularly updated (SalingSilang 2011). It is estimated that currently there are 2.7 million bloggers and more than 25 blogger communities in the country (Nugroho and Syarief 2012: p. 37). It would only be logical to assume that social media would have a significant social impact on Indonesians, particularly on those engaged in networking such as women entrepreneurs.

\footnotetext{
${ }^{3}$ Internet penetration level in Indonesia is actually low. It is reported in 2010 that only $9.1 \%$ of the population had access to the Internet. Meanwhile the neighbouring countries reached higher rate, for instance, $55 \%$ in Malaysia and 27.6 \% in Vietnam (International Telecommunication Union 2011). Access to the Internet is also mostly centralized in urban areas in the country. Despite the not-so-promising performance, the International Telecommunication Union (2011) reported that there were 220 million mobile phone users in Indonesia and many of them subscribed to mobile Internet services. Hence, this new service is able to increase Internet penetration in the country.

${ }^{4}$ Social media platforms such as Facebook, Twitter and YouTube have become standard features of affordable mobile phones. A Chinese brand mobile phone with SNS platforms is available in the Indonesian market for as low as Rp 100,000 (approximately USD 10). Branded mobile phones like Nokia can also be bought for less than Rp 500,000 (approximately USD 50). Moreover, Indonesian telecommunication providers offer reasonably reliable Internet connection for social networking activities for as low as Rp 25,000 (approximately USD 2.50) a month. Hence, mobile Internet users increased from 16.2 million in 2010 to 29 million in 2011 (Markplus 2011).
} 


\subsection{Research Objectives}

This study attempts to answer the following research questions: How does social media empower women? How does Internet technology impact women entrepreneurship?

Therefore, the main objective of this study is to contribute to the body of knowledge on the role of social media in empowering women through entrepreneurship. Additionally, the study aims:

- To generate insights on the potentials of social media in empowering women

- To determine how social media entrepreneurship can provide a balance between career and family life

This study is particularly significant since emerging studies on business and the Internet, more specifically social media, in Indonesia have been focusing only on marketing activities and rarely discuss the element of women entrepreneurship (see Handayani and Lisdianingrum 2011).

\section{Literature Review}

\subsection{The Internet, Social Media and Social Capital}

The Internet, considered as one of the greatest inventions of the twentieth century (Gates 2000), is considered a window for information democracy. The arrival of the Internet arguably opens many possibilities for many people. This is due to the fact that this new technology allows a more efficient way to communicate, so that not only communication is made faster but also relatively cheaper and accessible to many people with minimum skills. Internet power as the platform for the World Wide Web is manifested in Metcalfe's law, which states, 'the power of the Web is enhanced through the network effect produced as resource links by network members' (Esplen and Brody 2007: p. 14). As the number of people in a network grows, the connectivity between members also increases (ibid.). This characteristic is said to increase social capital among network users.

The power of the Internet in enhancing users' social capital can be seen more clearly in a new kind of service which has gained tremendous popularity, social media. With social media, people no longer form groups and connections exclusively within their physical locale. Instead, relationships are developed around geographically dispersed social networks. Social media themselves can be described as applications that 'allow the user to articulate an egocentric network, anchored by a profile' (Gross and Acquisti in Ellison et al. 2011: p. 876). One advantage of social media is their ability to help users manage both their weak and strong ties. Especially on sites such as Facebook, 'features to search people by name, region and school allows them to find and keep in touch with friends with whom they might 
have otherwise lost touch' (Ellison et al. 2011: p. 874). At the same time, users can also connect to casual acquaintances that might have some similarities with them, such as similar hobbies, occupations, educational backgrounds and so on.

Bourdieu (in Ellison et al. 2011: p. 874) defines social capital as 'the aggregate of actual or potential resources linked to a durable network of more or less institutionalized relationships of mutual acquaintance and recognition'. By this definition, social capital is the value or benefit that one gains from his or her social relationships and interactions (Burt in Ellison et al. 2011: p. 874). Similar to other types of capital, these benefits can come in many forms, such as access to information, companionship, financial gain and so on. Before the arrival of communication technologies, social capital was usually gained from face-to-face interaction and direct relationship; however the arrival of the Internet and other new media technologies changed this (Boase et al. 2006: p. 5). It is now argued that social capital is an integrated part of social media structures (Burt in Ellison et al. 2011: p. 874). It is because the significant number of users on social media with a diversity of backgrounds has resulted in increased social utility of these sites. Hence, social media can help users to be readily available and visible to a lot of different people (Brandtzæg et al. 2010: p. 1007).

Following its development, social media has been used more than just to find friends but to promote a social cause, to introduce a political candidate and more recently to conduct business. In Indonesia, particularly, there is a growing trend to open business ventures through social media. For instance, Facebook alone records that there are 549,740 users in Indonesia who are owners of small and medium enterprises (SMEs) and 176,300 of them are women (Facebook 2013). Flexibilities offered by social media become prominent contributing factors to the emergence of this trend. First of all, since social media accounts can be accessed through mobile technologies, such as smart phones or tablet computers, business can be done whenever and wherever they like. Furthermore, social media also allows products to be showcased in the virtual stores, thus eliminating the need to have a physical store - which is costly. In addition, the applications in social media are very userfriendly; users can tag pictures and provide information of products to potential customers by a single click.

The flexibilities described above also encourage women to become entrepreneurs. This arrangement is seen to be an ideal option for women for several reasons, among them being society's perception that favours women to stay at home, the dilemma faced by women between having a career and taking care of the children, the relatively low cost needed to open the business and so on. Among these reasons, the second one particularly attracts the interest of some scholars studying women online entrepreneurship (see Segal et al. 2005: p. 3; Lombard 2001: p. 216).

\subsection{Social Media Entrepreneurship}

The growing interest of women in developing an online business may also be supported by the nature of women who like to make contact with others. Furthermore, 
due to the limited time available, today's customers like to shop online as they can do it through the comfort of their computers or mobile phones. In terms of potential consumers for this kind of business, Indonesia is very promising. It is reported that Indonesia has one of the highest number of social media users with more than 35 million people (FI Management 2010). This resulted in the proliferation of businesses using social media as their communication platform, whether through sales offers or advertising.

Social media entrepreneurship offers many advantages to women. Not only does this business potentially support women to be financially independent, but in a more substantial level, social media business encourages women to be more selfactualized. According to Abraham Maslow, which places self-actualization in his last level of hierarchy of needs, self-actualization is the one factor that makes a human being 'fully human' (in Goble 1970: p. 25). The importance of selfactualization helps women not only to cultivate themselves but also to increase their self-esteem. All of these lead to women having a stronger position in the family and society, thus contributing to their empowerment.

\subsection{Women Empowerment}

According to Mosedale (2005: p. 246), the concept of women's empowerment began in the 1970s, initiated by third-world feminists and women organizations. In the 1990s, the concept evolved, and many agencies began to associate it with strategies to provide support to increase women productivity in relation to the increasing withdrawal of state responsibility for broad-based economic and social assistance. However, despite the fact that the strategies provide women with more access and control over household finances, there are those who argue that this claim may be overrated. According to Mayoux (in Mosedale 2005: p. 246), without the proper support networks and empowerment strategies, this condition actually gives more disadvantages to women since they will have to assume the burden for household debt and subsistence.

Empowerment itself is defined differently by different scholars. Constructing his definition on Narayan, Bennett (in Malhotra et al. 2002: p. 4) describes empowerment as 'the enhancement of assets and capabilities of diverse individuals and groups to engage, influence and hold accountable the institutions which affect them'. Meanwhile, Malhotra et al. (2002: p. 4) define empowerment as a term that is embedded by two important elements, which differentiate it from the general concept of 'power'. The first element is 'process' or 'change', which signifies empowerment as an improved condition from having less power to having more power and which enables individuals to gain social inclusion. The second element of empowerment is 'human agency', which refers to the freedom and willingness to exert one's choice without severe consequences. More detailed explanations of the terms will be discussed in later paragraphs. 
As mentioned above, in the first element of power, there is an important note on social inclusion that can be defined as 'the removal of institutional barriers and the enhancement of incentives to increase the access of diverse individuals and groups to assets and development opportunities' (Williams 2005: p. 3). This view of empowerment is supported by Kabeer (1999: p. 436) who argues that being empowered is not only about having choices but also more importantly about having the freedom to exercise these choices. Based on these definitions, it can then be concluded that empowerment incorporates three interrelated dimensions, which are resources (preconditions), agency (process) and achievements (outcomes). Moreover, they highlight that empowerment is not only referring to access to resources, usually associated with the poor. Those who are not considered poor may also be involved in the process of change to be empowered, such as having more choices, control, freedom and so on. In addition, resources should not only be understood as material resources in the more conventional economic sense (such as money, land, etc.) but also the various human and social resources which serve to enhance the ability to exercise one's choice (skills, education, supports, etc.). Resources in this broader sense are acquired through different social relationships, such as family, market and community (Kabeer 1999: p. 437).

On the other hand, the second dimension of power is related to agency or the ability to define one's goals and act upon them (Kabeer 1999: p. 437). Agency itself does not simply mean an action to exercise one's choice; instead it also 'encompasses the meaning, motivation and purpose which individuals bring to their activity, their sense of agency, or "the power within" (ibid.). Apart from being commonly understood as a decision-making process, agency can actually take a number of other forms, such as bargaining and negotiation, deception and manipulation, subversion and resistance as well as more intangible, cognitive processes of reflection and analysis (ibid.). This dimension can also be exercised either by an individual or by groups. In relation to power, agency has both positive and negative implications. In the positive sense, agency refers to people's capacity to define their own life choices and to pursue their own goals, even in the face of opposition from others. On the other hand, agency can also mean a 'power over' or 'the capacity of an actor or category of actors to override the agency of others, for instance, through the use of violence, coercion and threat' (ibid.). The two dimensions of power - resources and agency - combined reflect what Sen (1985) refers to as capabilities or 'the potential that people have for living the lives they want'.

There are several aspects of women empowerment as proposed by different theorists such as Acharya and Bennett (1983), Kabeer (1997) or Frankenberg and Thomas (2001). However, for purposes of this study, only the economic, sociocultural, familial/interpersonal and psychological dimensions will be examined. In addition, this study will use several indicators, which are proposed by Malhotra et al. (2002: p. 26) to measure women empowerment. These include domestic decisionmaking, access to or control over resources, freedom of movement, economic contribution to household, appreciation in household, sense of self-worth, time use/division of domestic labour and knowledge. 
Reflecting back from the above explanations, it can be concluded that empowerment is an ongoing process and should not be seen as a result since the environment within which empowerment operates continuously changes. Hence, the empowered condition cannot be maintained unless the agents continuously challenge the power system that suppresses their rights. Entrepreneurship is seen as one potential tool to fulfil this objective. It is due to the fact that the increasing role of women as entrepreneurs or as financial contributors in the family leads to increasing power over the decision-making in the family. Researches have concluded that the increase of women's access to activity within the market correlates with the increase of their authority within the household and community (Coughlin and Thomas 2002). Positive results also arise with the increasing empowerment of women as entrepreneurs which improves the education, health and productivity of the household members, particularly the children (Coughlin and Thomas 2002: p. 557). Nonetheless, it should be noted that although these literature and research on entrepreneurship emphasize its ability as an economic engine with potential social impacts, Calás et al. (2009: p. 560) suggest a different point of view of entrepreneurship that entrepreneurship should be seen more as a social change activity with a variety of possible outcomes that may or may not be beneficial for the entrepreneur.

\subsection{Women Entrepreneurs}

Sicat (2007) identified that there are generally two types of women entrepreneurs. The first is the subsistence entrepreneur where women, particularly in low-income households, are driven to generate supplementary income due to their concern about the basic needs of the family. The second type is defined as the growth entrepreneur, where women tend to be the modern, career-minded and working for the purpose of self-actualization. Many women state that their primary motivation in starting up a business is to meet personal and business goals, as well as to go against stereotypes imposed by society (Roffey et al. 1996).

The reality today is that women play a much bigger role in the economic empowerment within the family as well as within the society. In Indonesia, the State Ministry of Cooperatives and Small and Medium Enterprises estimates in 2006 that $60 \%$ of the micro-, small and medium enterprises are owned by women. In the same year, about $85 \%$ of Indonesian Women's Business Association members were owners of micro- and small businesses (Sarinastiti 2006: p. 10). Other parts of Asia also experience the growing phenomenon with about $35 \%$ of small and medium enterprises (SMEs) headed by women (Chiam 2001). Taking into account that SMEs make up $95 \%$ of all enterprises in the Asia-Pacific region and contributing between 30 and $60 \%$ of GDP in each APEC economy (Chiam 2001), it is not hard to see the significant role women play within the economy. This is also evident in China where about $25 \%$ of business start-ups are conducted by women (Chiam 2001) as well as in Japan which holds the staggering statistical domination by women in the SMEs, 
where four out of five small business owners are women (Chiam 2001). Given these trends, the study intends to contribute to the existing body of knowledge on women, social media, entrepreneurship and empowerment.

\section{Research Methods}

Five focus group discussions with women entrepreneurs in the five largest Indonesian cities (Jakarta, Surabaya, Bandung, Medan and Makassar) were conducted. Fifty-two women participated in these FGDs. The participants were snowball sampled using the following selection criteria: married women in their productive age, lived in one of the five largest cities in Indonesia and owned an online business that made use of social media, either individually or with a partner(s), as a full-time job for at least 2 years.

The FGDs solicited their stories on their use of social media in their businesses and its impact on their life. Following this, in-depth interviews were conducted with one participant in each city. The interviews were conducted in the participant's house with the purpose of experiencing first-hand how the participant manages her business in between her daily activities. Both the FGDs and interviews were video and audio recorded.

At the beginning of the FGDs, questionnaires were distributed to solicit respondents' socio-demographic information and online business details including type of business, clientele, assets, liabilities, income and so on (Fig. 1).

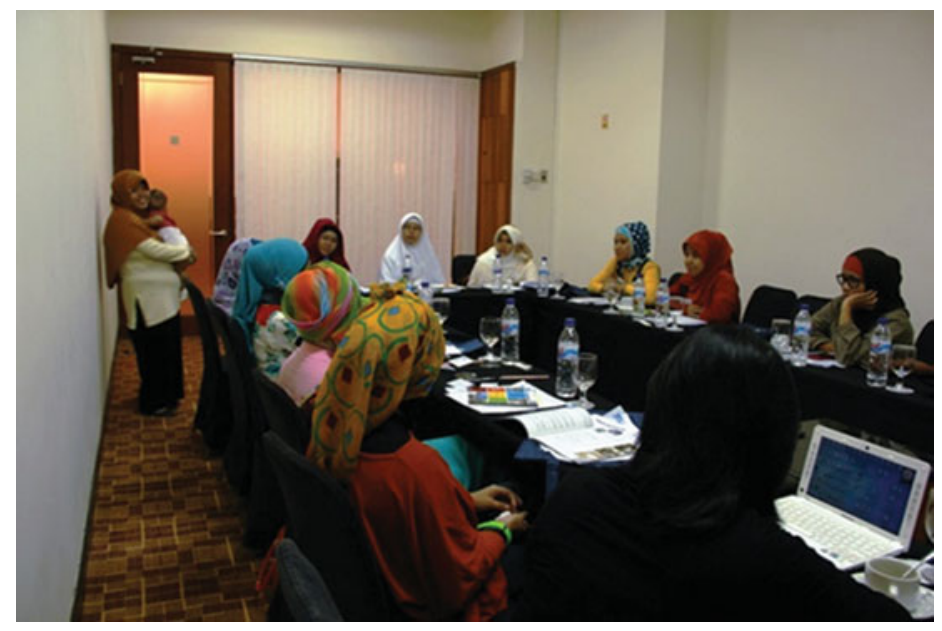

Fig. 1 Focus group discussion in Makassar, South Sulawesi 


\section{Findings and Discussion}

\subsection{Respondents' Profiles}

From the questionnaires, the following data can be derived:

First of all, with regard to demographic characteristics, most of the women are between the ages of 31 and 40 years old (54\%), $22 \%$ are between the age of 20 and 30 years old and $20 \%$ are between the age of 41 and 50 years old, while the oldest are between the ages of 51 and $60(4 \%)$.

In addition, most respondents have high education level with $25 \%$ claiming to hold a master's degree, $73 \%$ holding a bachelor's degree and only one person ( $2 \%)$ stating that she only graduated from high school. Many of these women once pursued a professional career $(70 \%)$, while $22 \%$ stated that they had never worked, and $8 \%$ started the business straight away after finishing their studies.

Furthermore, some information was also gathered with regard to their business. The questionnaire revealed that around $70 \%$ of these women sell home-made cakes or other food products, while the rest mostly sell fashion products targeted mainly for women. In terms of income made from these businesses, $40 \%$ reported that they earn approximately 2.5 to 5 million a month (approximately USD 250-USD 500), while $26 \%$ mentioned that they earn between 5 and 7.5 million, $24 \%$ earn below 2.5 million, and only $10 \%$ earn above 7.5 million.

Although there were not any specific questions in the questionnaire asking about their computer literacy and usage, all respondents mentioned in the FGDs that they learned some basic computer skills during their studies. Those who worked acquired more advanced skills at the office, while others only developed their skills when they decided to establish the online business.

\subsection{Networking and Social Capital}

Social capital has been one of the main drivers of women's entrepreneurship. Online businesses are started, developed and maintained with the support of online communities and friends. Such was validated in this study.

Among the respondents, leaving work to take care of families served as a catalyst for opening an online business. Initially, the loss of daily interaction with peers at work or within their social circles prompted them to find other means to interact. The Internet offered a solution to be virtually present to their peers by interacting through technology-mediated conversations while at the same time being available for their families and their daily domestic activities. In time, these online interactions grew and turned into a potential source of income. 


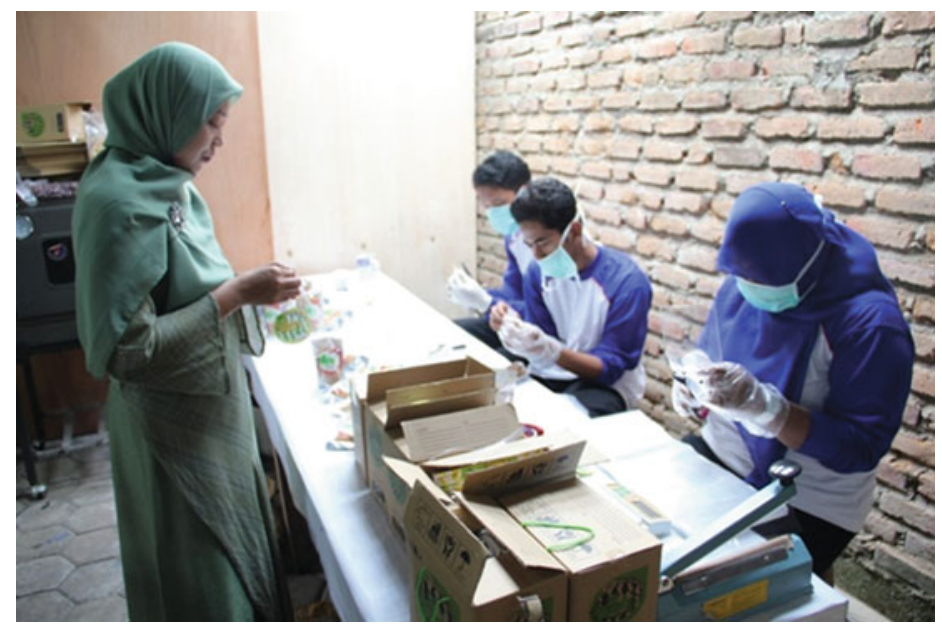

Fig. 2 A respondent in Surabaya controlling the production process in her home

Aside from being a medium of communication between the respondents and their peers, the platform also attracted other bloggers who were interested in similar topics. Conversations were initiated through comments or requests. The networks grew and some groups became established communities.

This (business) community is very supportive. We can ask each other information on what products are trendy right now. Then, I can ask others if I run out of stock. Simply, we help each other. (A respondent from Bandung)

Online community members take friendship in the virtual world to be as serious as in the physical world. They have devoted as much time and effort or perhaps even more to these friendships. Their activities may be the means to achieve an end of 'what would I post on my social media today?' Baking cookies and trying out certain recipes become the activities that were not purely motivated to provide for the family but also to provide the experience and photos to be posted up and shared among peer groups in social media (Fig. 2).

These online interactions grew. To accommodate the communities' need to interact in person, gatherings are often conducted. Depending on the common interest of the group, these gatherings are also done for a certain purpose. In the culinary online business, for example, events would include workshops in making currently popular food products or about food photography. There are also communities that conduct events for networking among members in support of their online businesses.

\subsubsection{Knowledge Sharing and Reuse}

The majority of the respondents opened their social media accounts for the sole purpose of interacting with their peers rather than to set up online businesses. 
However, the medium has proved to be valuable where their interactions enabled them to identify peers who have similar interests, including in establishing online businesses. In such cases, these friendships were developed and strengthened even further by the sharing of experiences of their entrepreneurial activities. Some even started out their business inspired by peers who had been online entrepreneurs. Reciprocally, the entrepreneur's increasing involvement in the business and the more success they received from their business encourage them to give support to inspired peers who want to follow on their footsteps in online entrepreneurship.

However, it was found that a significant number of respondents started from zero online capital and were advised by their offline environment to use social media to market their products. Their network increased gradually by adding more people based on the personalities that matched the products or services they offered. Their closest peers' networks serve as their initial points in searching for personalities in the category of their target market. Their peers' network is likely to be more easily approached, and request to enter their target consumer's network is more easily approved due to the existence of mutual friends.

These mutual friends are considered very important not only in expanding one's networking but also as points of references in promoting their online business. The women entrepreneurs often used testimonials from friends to convince others about the quality of their products and services. Photos posted up on the Internet would not be convincing enough because they only appeal to the visual sense. Other senses such as tasting and smelling of a product may have to depend on others' testimonials. Testimonials such as the fast response of the shops in answering customer's inquiry as well as fast delivery are also considered important.

In NCC (a food and cooking community) I can pass orders to other members. For instance if I'm busy and can't take orders, I just call my friend to take that order. My regular customers trust me as I am the one recommending this friend. (A respondent from Bandung)

\subsection{Self-Actualization and Economic Gain}

The biggest benefits of doing online business from homes for the women are selfactualization and economic gain. Being merely a housewife makes most women feel uncomfortable and unproductive. Online business also enables women to make money and contribute to their household finance.

\subsubsection{Sense of Self-Worth}

The change of pace from working outside to becoming a housewife took its toll on some. Many expressed their frustration in the initial stage of changing from a busy office worker to a housewife. This is particularly true for those whose babies have grown and demand less of their time. Being 'idle' after completing daily housework has led them to seek other forms of self-actualization. The Internet then became 
a primary source where they can start exploring activities that can be done while raising the family. Those who are interested in culinary arts would seek recipes from the Internet to make at home and would share their experience on blogs and the likes.

Testimonies from the respondents reveal how social media increased their sense of self-worth. Most of them used blogs and other personal accounts from social networking services to present themselves virtually to their peers. These platforms are used to post their daily achievements such as personal cooking recipes and photos of their finished products.

I want others to see that I do not only take care of the children, that I actually work although

I stay at home. (A respondent from Jakarta)

\subsubsection{Appreciation by the Family}

Upon leaving their employment and focusing on their families, the respondents may feel that they are not contributing much. This has to do with the pressure from the society who sees that being a stay-at-home mother is somewhat an unproductive choice. In many cases, those who have acquired a university degree may receive some criticism from family members who see it as a waste of time to study after a degree if not to be used for work for some companies. In facing such dilemma, the respondents would turn to others who are experiencing similar situations within their offline and online communities for support. These supports may be in the form of motivation and encouragement from the communities for them to continue with their decision to work while staying at home and be successful with their choice.

At the beginning, my husband was in doubt. He didn't think that I could create something that people would buy. After my business started to grow he began to believe in me. With this business, I feel more appreciated, that we are actually not inferior to the husband. (A respondent from Makassar)

Mastering the Internet becomes a challenge for the respondents who may even have to keep up with their digitally native children. It becomes a need to know the Internet and not being considered as 'web illiterate', both at home and outside. Selfactualization is recognized by the respondents as an individual need that should be satisfied whether from working outside or from home. But just as their decision to leave work was motivated by family, so too is the need for self-actualization. Through succeeding in their online business, they aim to make their family proud of them as businesswomen and to improve the family's welfare through gaining financial freedom and contributing to the family's expenses.

Many of the women used the knowledge that they gained while under employment to start their business. Those who may have been using the Internet extensively prior to quitting work and focusing on family may find it easier to start their online business since they are somewhat familiar with virtual environment. Some respondents have already opened up the online business while they are under employment but had to choose to focus on the latter as the business grew and proved 
to have more potential than their current work. For these women, focusing on their online business serves as a favourable solution where they can enjoy the flexibility of working at home while taking care of family.

\subsubsection{Economic Contribution to the Household}

The main motivation for the respondents to set up their online business is for financial gain while at the same time being able to stay home. For most of the respondents who were under employment, quitting work and focusing on the family means cutting the family's source of income to solely rely on their husbands. With no fixed individual income, they no longer have the freedom to purchase things to their likings and have to focus more on the basic family needs. Their desire is to have financial freedom without having to leave home to work.

Although, I don't earn so much but at least I can supplement my husband's income. I'm grateful about that. (A respondent from Medan)

Now, if I want to buy something for my children or take her for leisure activities, I don't need to ask my husband's permission. (A respondent from Makassar)

Encouragement and support from husbands are most important in helping the women to set up their online business. Many of the husbands feel that the respondents need self-actualization, to be productive and to continue to socialize by expanding their knowledge and capacity as individuals. The family feels the benefit from the respondents as they started their online business as it gives good examples for the children to learn from as well as giving the financial contribution.

I don't want my daughter to think that I am only a mere housewife. I want to set good examples for her. (A respondent from Jakarta)

\subsection{Domestic Issues}

The main motivation for the women to quit working is due to the demand to take care of the growing family. In some cases, the respondents' husbands specifically requested them to put their career on hold and to focus more on the children, as having both parents working outside is not seen to be favourable for the children. Leaving children in the hands of others is considered quite risky for their development. Moreover, getting hired to help raise children is considered increasingly difficult, and many would have to resort to relinquishing work to focus more on the family.

\subsubsection{Freedom of Movement}

The respondents felt that the online business enabled them to be self-actualized without the restraint of working for others. Some may argue that not having a 
superior to watch over them or to take orders from and being able to do the business to their liking and to suit their needs would be much more preferable.

Now we can decide when we want to work. When I worked (as a teacher), my daughter always complained that I didn't have time to play with her. Now, we are with her every day. She is so happy when she tells the neighbour "My mommy doesn't work anymore". (A respondent from Medan)

Moreover, many of the respondents feel that by working outside home, they miss out on their children growing up. They feel that working in offices takes up too much of their time and energy, and by doing so, oftentimes they feel that they are abandoning their children. This attitude is also applied to their online business where for some respondents, the business comes second after their children, and they only respond to the customers' queries when they are free from their domestic duties. Although they realized that this is not a good way to run their business, they continuously return to why they quit work in the first place (Fig. 3).

However, the above attitude is not followed by others. There are cases where their thriving business comes first and they would spend more time on it than they do on their families. Some admit of not taking much care of their children because they are too heavily involved on the online interaction, starting their online interaction once they are awake and go right through the late night hours. This usually occurs in the initial stage of their business where they have to spend more effort in setting up their business before reaching their learning curve. Balancing between their business and family is what most would strive for as most admit that it is not easy. Their neglect of the family has more to do with their need to generate income from the online business for the family.

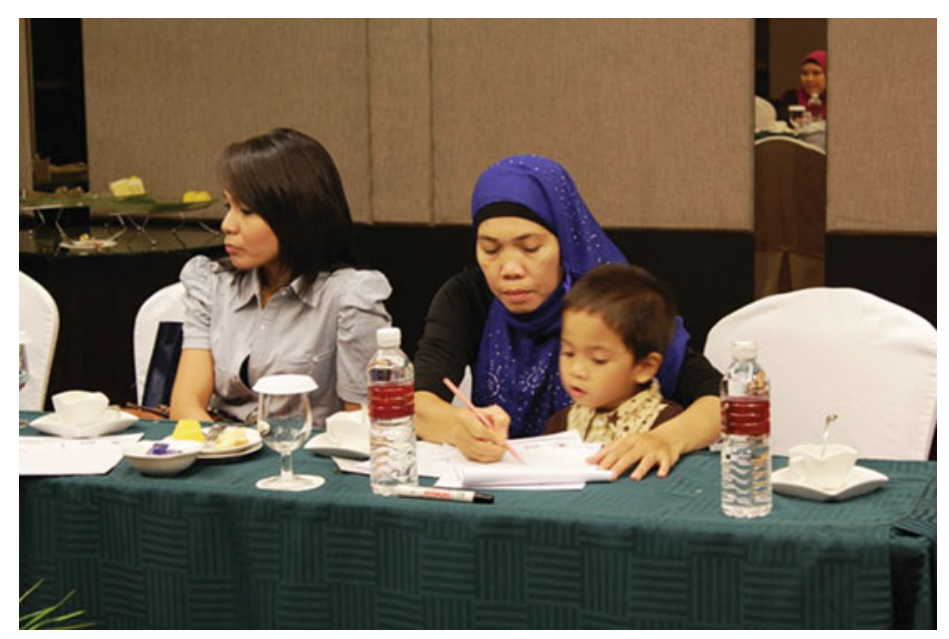

Fig. 3 A respondent from Bandung had to bring her child to the FGD session as she could not find anyone to look after him 


\subsubsection{Domestic Decision-Making}

Having their own income also improves these women's position in the family. Respondents reported that they can now contribute more actively to the family decision-making and other family members give more values towards their opinions.

When my husband saw the potentials of this business, he was impressed. Now he even decides to resign from his work so that he can manage this business together to make it grow. (A respondent from Surabaya)

In addition, these women also feel that they can now negotiate more equality in the household chore division. Before, their husbands seemed to think that it is their role as housewives to take care of the house and the children. Now, by seeing that these women have many things in between their roles as housewives and as entrepreneurs, husbands tend to be more willing to help at home, such as by feeding the children, washing the dishes and so on.

\section{Conclusions and Implications}

As the narrative of social media and women entrepreneurs in Indonesian society is still evolving, this study contributes to the conversation. The findings confirm that online businesses have great potential in empowering women by assisting them to become entrepreneurs. In addition, social media entrepreneurship can be seen as a solution to the dilemma faced by women in managing and balancing between their career and family life.

\subsection{How Does Social Media Empower Women?}

The study showed that social media expanded the social networks of the respondents and subsequently increased their social capital as argued by the current literature on networking. Social media contributed to their sense of self-worth and increased their knowledge.

\subsection{How Does Internet Technology Impact Women Entrepreneurship?}

The narratives of the women entrepreneurs who participated in the study submit that Internet technology added to their self-actualization and economic gain. They were more appreciated by their family including their husbands who initially objected to 
their self-employment. They were able to contribute substantively to the household economically. They had freedom of movement and more active participation in domestic decision-making.

\subsection{Implications}

In spite of the positive testimonials in the foregoing discussion, Indonesian society still views conventional employment as more favourable because of its stability when compared with high-risk self-employment. The low number of entrepreneurial activities in Indonesia may be an indicator of this trend. The introduction of online entrepreneurship may change this perception.

The potential of social media for businesses has yet to reach its full potential. While some respondents agree that the offline market may be too saturated, the online market is still far from being explored. The low start-up cost of the social media enabled those who are lacking in capital to still open up their businesses. For businesses that produce the products such as cake shops, they can buy the raw materials when they received orders, reducing the risk of sales. Businesses that only act as distributors can distribute photos of their products and only buy the products when they received the orders. This way, the capital needed to run the business is at its lowest.

Ultimately, women social media entrepreneurship would progress in Indonesia due to its unique features that include: mobility and flexibility promoted by social media, social capital gained through social media interactions, unequal distribution of products in Indonesian cities and lack of time among customers to shop and confidence and satisfaction women gained from doing this business.

Open Access This chapter is distributed under the terms of the Creative Commons Attribution Noncommercial License, which permits any noncommercial use, distribution, and reproduction in any medium, provided the original author(s) and source are credited.

\section{References}

Acharya, M., \& Bennett, L. (1983). Women and the subsistence sector: Economic participation and household decision-making in Nepal (Working Paper No. 526). Washington, DC: World Bank.

Antara. (2012). Indonesia butuh 4,76 juta wirausahawan. Viewed on October 21, 2012, from http:// www.antaranews.com/berita/338483/indonesia-butuh-476-juta-wirausahawan

Ardieansyah, A. H., Rozman, A. M. Y., \& Buang, A. (2011). The imperative of training for women economic empowerment - Statistical evidence from Indonesia. World Applied Sciences Journal, 13, 39-45.

Badan Pusat Statistik. (2010). Keadaan ketenagakerjaan Agustus 2010 (Official Report No. 77/12/Th. XIII). Jakarta: Badan Pusat Statistik. 
Boase, J., Horrigan, J. B., Wellman, B., \& Rainie, L. (2006). The strength of internet ties: The internet and email aid users in maintaining their social networks provide pathways to help when people face big decisions. Washington, DC: Pew Internet and American Life Project.

Brandtzæg, P. B., Lüders, M., \& Skjetne, J. H. (2010). Too many Facebook "friends"? Content sharing and sociability versus the need for privacy in social network sites. International Journal of Human-Computer Interaction, 26(11-12), 1006-1030.

Calás, M., Smircich, L., \& Bourne, K. (2009). Extending the boundaries: Reframing entrepreneurship as social change through feminist perspectives. Academy of Management Review, 34(3), 552-569.

Carney, M., Dieleman, M., \& Sachs, W. (2008). The value of social capital to family enterprises in Indonesia. In P. H. Phan, S. Venkataraman, \& R. Velamuri (Eds.), Entrepreneurship in emerging regions around the world: Theory, evidence and implications. Cheltenham: Edward Elgar.

Chiam, V. (2001). E-commerce technologies and networking strategies for Asian women entrepreneurs. In Proceedings of the 2nd conference on Women Entrepreneurs in SMEs, OECD. Bercy: France.

Coleman, S. (2000). Access to capital and terms of credit: A comparison of men- and womenowned small business. Journal of Small Business Management, 38(6), 523-541.

Coughlin, J. H., \& Thomas, A. R. (2002). The rise of women entrepreneurs: People, processes, and global trends. Westport: Quorum Books.

Cromie, S., \& Birley, S. (1992). Networking by female business owners in Northern Ireland. Journal of Business Venturing, 7(3), 237-251.

Danani, S. (2004). Unemployment and underemployment in Indonesia, 1976-2000: Paradoxes and issues. Geneva: International Labour Organization.

Duncombe, R., Heeks, R., Morgan, S., \& Arun, S. (2005). Supporting women's ICT-based enterprises: A handbook for agencies in development 2005. Manchester: Institute for Development Policy and Management (IDPM). Viewed October 1, 2012, from http://www.sed.manchester. ac.uk/idpm

Ellison, N. B., Steinfield, C., \& Lampe, C. (2011). Connection strategies: Social capital implications of Facebook-enabled communication practices. New Media \& Society, 13(6), 873-892.

Esplen, E., \& Brody, A. (2007). Putting gender back in the picture: Rethinking women's economic empowerment. Sussex: BRIDGE (Development - Gender), Institute of Development Studies, University of Sussex.

Facebook. Viewed April 25, 2013, from http://www.facebook.com/ads/create/

FI Management. (2010). Indonesia: A social media nation. FI Management, 12 April 2011. http:// www.fimanagement.com

Frankenberg, E., \& Thomas, D. (2001). Measuring power: Food consumption and nutrition division (Discussion Paper No. 113). Washington, DC: International Food Policy Research Institute.

Gates, B. (2000). Shaping the Internet age. Washington, DC: Internet Policy Institute.

Goble, F. (1970). The third force: The psychology of Abraham Maslow. Richmond: Maurice Bassett Publishing. http://en.wikipedia.org/wiki/Maslow\%27s_hierarchy_of_needs-cite_ref-6

Gold, T., \& Guthrie, D. (2002). Social connections in China: Institutions, culture, and the changing nature of Guanxi (Vol. 21). Cambridge: Cambridge University Press.

Handayani, P. W., \& Lisdianingrum, W. (2011). Impact analysis on free online marketing using social network Facebook: Case study SMEs in Indonesia. In Paper presented at the Advanced Computer Science and Information System (ICACSIS), 2011 international conference. Jakarta.

International Telecommunication Union. (2011). ICT statistics, Geneva. Viewed on October 1, 2012, from http://www.itu.int/ITU-D/ict

Internet World Stats. (2012). Internet World Stats. Viewed October 12, 2012, from http://www. internetworldstats.com/stats.htm

Jones, B. (2010). Entrepreneurial marketing and the Web 2.0 interface. Journal of Research in Marketing and Entrepreneurship, 12(2), 143-152.

Kabeer, N. (1997). Women, wages and intra-household power relations in urban Bangladesh. Development and Change, 28, 261-302. 
Kabeer, N. (1999). Resources agency, achievements: Reflections on the measurement of women's empowerment. Development and Change, 30, 435-464.

Kementrian Koperasi dan Usaha Kecil Menengah. (2008). Undang Undang No. 20 Tahun. Republik Indonesia. Jakarta.

Kementrian Pemberdayaan Perempuan dan Perlindungan Anak. (2011). Perkembangan data usaha mikro, kecil, dan menengah (UMKM) dan usaha besar (UB) tahun 2010-2011. Jakarta: Kementerian Pemberdayaan Perempuan dan Perlindungan Anak.

Lombard, K. V. (2001). Female self-employment and demand for flexible, non-standard work. Economic Inquiry, 39(2), 214-237.

Malhotra, A., Schuler, S., \& Boender, C. (2002). Measuring women's empowerment as a variable in international development. International Center for Research on Women and the Gender/Development Group of the World Bank. Washington D.C.

MarkPlus Insight. (2011). Pengguna Internet di Indonesia. MarkPlus Insight: Jakarta.

Mosedale, S. (2005). Assessing women's empowerment: Towards a conceptual framework. Journal of International Development, 17, 243-257.

Ndubisi, N. O., \& Kahraman, C. (2006). Malaysian women entrepreneurs: Understanding the ICT usage behaviour and drivers. Journal of Enterprise Information Management, 18(6), 731-739.

Nguyen, M. (2005). Women entrepreneurs: Turning disadvantages into advantages. PreFlight Ventures. Viewed October 1, 2012, from http://www.preflightventures.com/resources/ WomenEntrepreneursLitSurvey012005.htm

Nugroho, Y., \& Syarief, S. S. (2012). Beyond click-activism? New media and political processes in contemporary Indonesia. Jakarta: Friedrich-Ebert-Stiftung.

O'Reilly, T. (2009). What's next for web 2.0, O'Reilly. Viewed August 12, 2011, from http://oreilly. com/web2/archive/what-is-web-20.html

Roffey, B., Stanger, A., Forsaith, D., McInnes, E., Petrone, F., \& Symes, C. (1996). Women in small business: A review of research. Canberra: Australian Government Publishing Service.

SalingSilang. (2011, February). Indonesia social media landscape. Viewed April 12, 2011, from http://www.salingsilang.com

Sarinastiti, I. (2006). IFC highlights women's entrepreneurship in Indonesia: IFC-PENSA and IWAPI launch "voices of women in the private sector". Jakarta: International Finance Corporation.

Sarri, K., \& Trihopoulou, A. (2005). Female entrepreneurs' personal characteristics and motivation: A review of the Greek situation. Women in Management Review, 20(1), 24-36.

Segal, G., Borgia, D., \& Schoenfeld, J. (2005). The motivation to become an entrepreneur. International Journal of Entrepreneurial Behaviour \& Research, 11(1), 42-57.

Sen, A. (1985). Commodities and capabilities. Amsterdam: North-Holland.

Sicat, M. (2007). Impact of improved communication on women's transport needs and empowerment in Bangladesh. In Gender and transport (Transport and communications bulletin for Asia and the Pacific, Vol. 76, pp. 72-88). New York: United Nations Economic and Social Commission for Asia and the Pacific.

Siong-Choy, C. (2007). Theorising a framework of factors influencing performance of women entrepreneurs in Malaysia. Journal of Asia Entrepreneurship and Sustainability, 3(2), 42-59.

Socialbakers. (2012). Indonesia Facebook statistics. Viewed December 12, 2012, from http://www. socialbakers.com/facebook-statistics/indonesia

Van der Merwe, S. P., \& Lebakeng, M. (2010, August 25-26). An empirical investigation of women entrepreneurship in Lesotho. Paper presented at the African International Business and Management conference. Nairobi.

Widyadari, S., Shrader, H., \& Pranoto, H. (2006). Suara-suara perempuan pengusaha. Jakarta: IFC-PENSA and IWAPI.

Williams, J. (2005). Measuring gender and women's empowerment using confirmatory factor analysis. Boulder: Population Program, Institute of Behavioural Science, University of Colorado. 